\title{
Heart rate variability in critical care medicine: a systematic review
}

\author{
Shamir N. Karmali, Alberto Sciusco, Shaun M. May and Gareth L. Ackland
}

\author{
* Correspondence: \\ g.ackland@qmul.ac.uk \\ Translational Medicine \& \\ Therapeutics, William Harvey \\ Research Institute, Queen Mary \\ University of London, John Vane \\ Science Centre, Charterhouse \\ Square, London EC1M 6BQ, UK
}

\begin{abstract}
Background: Heart rate variability (HRV) has been used to assess cardiac autonomic activity in critically ill patients, driven by translational and biomarker research agendas. Several clinical and technical factors can interfere with the measurement and/or interpretation of HRV. We systematically evaluated how HRV parameters are acquired/processed in critical care medicine.
\end{abstract}

Methods: PubMed, MEDLINE, EMBASE and the Cochrane Central Register of Controlled Trials (1996-2016) were searched for cohort or case-control clinical studies of adult (>18 years) critically ill patients using heart variability analysis. Duplicate independent review and data abstraction. Study quality was assessed using two independent approaches: Newcastle-Ottowa scale and Downs and Black instrument. Conduct of studies was assessed in three categories: (1) study design and objectives, (2) procedures for measurement, processing and reporting of HRV, and (3) reporting of relevant confounding factors.

Results: Our search identified 31/271 eligible studies that enrolled 2090 critically ill patients. A minority of studies $(15 ; 48 \%)$ reported both frequency and time domain HRV data, with non-normally distributed, wide ranges of values that were indistinguishable from other (non-critically ill) disease states. Significant heterogeneity in HRV measurement protocols was observed between studies; lack of adjustment for various confounders known to affect cardiac autonomic regulation was common. Comparator groups were often omitted $(n=12 ; 39 \%)$. This precluded meaningful meta-analysis.

Conclusions: Marked differences in methodology prevent meaningful comparisons of HRV parameters between studies. A standardised set of consensus criteria relevant to critical care medicine are required to exploit advances in translational autonomic physiology.

Keywords: Autonomic, Heart rate variability, Human, Systematic review

\section{Background}

Autonomic changes are evident from the onset of acute pathology requiring critical care. Cardiac autonomic function can be derived by analysing variability between heart beats to yield time domain and frequency domain (power spectral density) measures that reflect autonomic modulation of cardiac frequency [1, 2]. Heart rate variability (HRV) appears to contribute diagnostic and prognostic value in various cardiometabolic conditions associated with subclinical autonomic dysfunction that predispose to critical illness including hypertension, coronary artery disease, heart failure and

(C) The Author(s). 2017 Open Access This article is distributed under the terms of the Creative Commons Attribution 4.0 International License (http://creativecommons.org/licenses/by/4.0/), which permits unrestricted use, distribution, and reproduction in any medium, provided you give appropriate credit to the original author(s) and the source, provide a link to the Creative Commons license, and indicate if changes were made. 
diabetes [3-7]. Similarly, HRV has been proposed to serve as a potential diagnostic and prognostic tool in critically ill patients [8].

However, HRV measures in critically ill patients are fraught with potential problems. [9] Although population norms for HRV parameters have been reported in healthy populations [10], the impact of multiple physiological, procedural and technical factors in critically ill patients has not undergone systematic scrutiny in critical care medicine [11]. Moreover, the validity of HRV as a tool to interrogate autonomic function is increasingly under physiological scrutiny [12, 13], since a strong correlation between HRV and morbidity/mortality appears to be largely attributable to incident heart rate. In addition, recording technique, clinical context and adjustment for incident heart rate are key factors to consider when interpreting the translational relevance of HRV in critically ill patients.

Here, we sought to systematically evaluate the methodology and design of HRV studies in critical care medicine. We focused on whether recommended standards for measurement and reporting have been employed [14, 15], with the aim of identifying areas to refine in future HRV experimental design in critical care medicine.

\section{Methods}

\section{Identification of studies}

A literature review was performed based on the Preferred Reporting Items for Systematic reviews and Meta-Analyses (PRISMA) guidelines for systematic reviews [16]. The summary of the search strategy employed is shown in Additional file 1.

We searched the electronic databases PubMed, EMBASE, MEDLINE and the Cochrane Central Register of Controlled Clinical Trials for articles investigating HRV measurement in intensive care patients. Inclusion criteria were full-text studies written in English involving adult patients, published after 1996 (following published guidelines) and reporting traditional time and frequency domain parameters [15]. Studies which reported newer analysis techniques of HRV (e.g. entropy analysis) were excluded, as we focussed on those reporting measures in line with recent European guidance [17]. The following Medical Subject Headings (MESH) were used to identify pertinent articles: "Heart rate variability OR HRV AND Sepsis", "Heart rate variability OR HRV AND multiple organ dysfunction OR MODS", "Heart rate variability OR HRV AND critical illness", "Heart rate variability OR HRV AND intensive care OR ICU". The last search took place on 9 November 2016. We screened articles by title search and abstract review. Relevant articles were analysed for eligibility, and further articles were identified from reference lists. Articles were excluded based on the following criteria: experimental studies, incorrect target population (adult; $>18$ years old), medical field other than intensive care, not original research, topic not within scope or traditional HRV parameters not reported.

\section{Data extraction}

Data was extracted by two independent reviewers (S.K and A.S) and recorded into a standardised excel sheet recording: author, year of publication, study design, number of subjects, mean patient age, proportion of male subjects, risk stratification score, comparator groups, study aim and outcome, study design, protocol for measurement, processing, analysis and reporting of HRV parameters, adjustment and reporting of 
confounding factors and quality assessment. We identified the following clinical confounding factors: age, gender, average heart rate, average respiratory rate, comorbidities, drugs, sedative drugs, vasoactive drugs, enteral nutrition and mechanical ventilation. Full details of the impact on HRV of these parameters are provided in Additional file 1. For reporting and analysis purposes, we selected the most commonly used time and frequency domain HRV parameters [15].

\section{Risk of bias and study quality assessment}

The quality of studies was assessed by two assessors independently (SK, SM) using two established tools (Newcastle-Ottowa scale, Downs and Black Instrument). The Downs and Black instrument is recommended by the Cochrane Collaboration for use in non-randomised and observational studies (Additional file 1) [18, 19]. Interobserver reliability evaluating quality within five domains: reporting, external validity, bias, confounding and power. Five questions were omitted because they are designed for interventional trials. The version which we employed in this study therefore has a maximum score of 22. Differences between reviewers were resolved by panel consensus opinion following further review of the article(s) in question by the senior author.

\section{Results}

\section{Study selection}

We identified 238 studies which underwent screening by title search and abstract review. From these, 31 articles involving 2090 patients (including controls) met the inclusion criteria for assessing the role of HRV in critically ill patients [20-53]. Two articles analysed the same cohort of patients [34, 37].

\section{Study characteristics}

Demographic and clinical data, including comparator groups are summarised in Table 1. All articles reported cohort or case-control studies. The average age of patients was $60 \pm 7$ years. The majority of studies $(22 / 31 ; 71 \%)$ explored the association between HRV measures, morbidity and mortality. Key clinical findings from these studies are summarised in Table 2. Due to significant differences in trial design, methodology, confounding, non-standardised comparator groups and inconsistent reporting of summary data, a meta-analysis could not be performed. However, there was consistency between studies in their findings that LF/HF ratio was inversely associated with increased disease severity or mortality. For illustrative purposes, the individual effect sizes across six studies reporting mean and standard deviation data looking at disease severity and mortality using the most commonly reported HRV parameter (LF/HF ratio) are shown (Fig. 1).

\section{Quality of studies}

No studies reported Strengthening the Reporting of Observational Studies in Epidemiology (STROBE) guidelines. Two studies analysed data retrospectively. A minority of studies $(n=5 ; 16 \%)$ used individualised HRV data-i.e. patients serving as their own control, prior to an intervention. More than one third of studies $(n=13$; $42 \%)$ did not describe any comparator group. The remainder of studies used non-age 
Table 1 Demographics and study design of studies

\begin{tabular}{|c|c|c|c|c|c|c|}
\hline $\begin{array}{l}\text { Reference number. } \\
\text { author }\end{array}$ & Year & Study design & $\begin{array}{l}\text { Study populations } \\
( \pm \text { comparator group) }\end{array}$ & Patients $(n)$ & Age (mean \pm SD or mean [range]) & $\begin{array}{l}\text { Male } \\
(\%)\end{array}$ \\
\hline 20. Annane & 1999 & Case-control & Sepsis (healthy controls) & 26 & $\begin{array}{l}\text { Septic shock } 52 \pm 14 \\
\text { Sepsis } 54 \pm 17 \\
\text { Control } 43 \pm 11\end{array}$ & 65 \\
\hline 21. Korach & 2001 & Cohort & Sepsis & 41 & $50[20-90]$ & 44 \\
\hline 22. Barnaby & 2002 & Cohort & Sepsis & 15 & 59 [39-85] & - \\
\hline 23. Pontet & 2003 & Case-control & $\begin{array}{l}\text { Sepsis + MODS } \\
\text { (Sepsis - MODS) }\end{array}$ & 22 & $\begin{array}{l}\text { MODS } 59.5 \pm 17.8 \\
\text { Non-MODS } 60 \pm 10.4\end{array}$ & 64 \\
\hline 24.Shen & 2003 & Cohort & Weaning & 24 & $\begin{array}{l}\text { Successful wean } 76 \pm 12.9 \\
\text { Unsuccessful wean } 69.8 \pm 17.8\end{array}$ & 42 \\
\hline 25. Schmidt & 2005 & Cohort & $\begin{array}{l}\text { MODS } \\
\text { (literature values) }\end{array}$ & 85 & $60.4 \pm 14$ & 62 \\
\hline 26. Papaioannou & 2006 & Cohort & MODS & 53 & $63.02 \pm 14.68$ & 58 \\
\hline 44. Bourgault & 2006 & Cohort & Mixed aetiology & 18 & 60 [33-82] & 72 \\
\hline 45. Chen & 2007 & Cohort & Sepsis & 81 & $67[30-84]$ & 41 \\
\hline 50. Passariello & 2007 & Case-control & Ischaemic sudden death & 40 & $\begin{array}{l}\text { Sudden death } 66 \pm 8 \\
\text { Pathology matched controls } \\
68 \pm 8\end{array}$ & \\
\hline 46. Chen & 2008 & Cohort & Sepsis & 132 & 67 [27-86] & 47 \\
\hline 47. Aboab & 2008 & Case-control & $\begin{array}{l}\text { Sepsis } \pm \text { adrenal } \\
\text { insufficiency } \\
\text { (healthy controls) }\end{array}$ & 81 & $\begin{array}{l}\text { Septic shock and adrenal failure } \\
55 \pm 16 \\
\text { Septic shock } 58 \pm 19 \\
\text { Healthy controls (not provided) }\end{array}$ & 36 \\
\hline 27. Nogueira & 2008 & Cohort & Sepsis & 31 & $\begin{array}{l}\text { Survivors } 44.9 \pm 5.9 \\
\text { Non-survivors } 55.6 \pm 4.63\end{array}$ & 74 \\
\hline 28. Papaioannou & 2009 & Cohort & $\begin{array}{l}\text { Sepsis } \\
\text { (Sepsis SOFA <10) }\end{array}$ & 45 & 57.8 & - \\
\hline 51. Tiainen & 2009 & Cohort & $\begin{array}{l}\text { Out of hospital cardiac } \\
\text { arrest }\end{array}$ & 70 & $\begin{array}{l}\text { Hypothermia } 60 \text { (23-75) } \\
\text { Normothermia } 59(18-75)\end{array}$ & 86 \\
\hline 29. Schmidt & 2010 & Case-control $^{a}$ & MODS & 178 & $61.1 \pm 13.2$ & 67 \\
\hline 30. Kasaoka & 2010 & Cohort & SIRS & 10 & $53 \pm 15$ & 70 \\
\hline 31. Chen & 2012 & Case-control & $\begin{array}{l}\text { Sepsis and out of hospital } \\
\text { cardiac arrest } \\
\text { (Non-severe sepsis and } \\
\text { healthy controls) }\end{array}$ & 210 & $\begin{array}{l}\text { Out of hospital cardiac arrest } \\
68 \pm 10 \\
\text { Severe sepsis and mechanical } \\
\text { ventilation } 66 \pm 8 \\
\text { Severe sepsis } 68 \pm 7 \\
\text { Sepsis } 67 \pm 6 \\
\text { Healthy } 66 \pm 6\end{array}$ & 55 \\
\hline 32.Gomez Duque & 2012 & Cohort & $\begin{array}{l}\text { Sepsis } \\
\text { (literature values) }\end{array}$ & 100 & 55 [18-88] & 42 \\
\hline 33. Brown & 2013 & Cohort & Sepsis & 48 & 57 [40-63] & 46 \\
\hline 34. Green & 2013 & Cohort & MODS & 33 & $56.5 \pm 15.9$ & 61 \\
\hline 35.Wieske & 2013 & Cohort & ICU acquired weakness & 83 & $\begin{array}{l}\text { ICU acquired weakness } 60 \pm 13 \\
\text { No ICU acquired weakness } \\
59 \pm 16\end{array}$ & 60 \\
\hline 36. Wieske & 2013 & Cohort & $\begin{array}{l}\text { Mixed aetiology } \\
\text { (healthy controls) }\end{array}$ & 32 & $\begin{array}{l}\text { Patients } 54 \pm 15 \\
\text { Healthy control } 36 \pm 2\end{array}$ & 70 \\
\hline 37. Bradley & 2013 & Cohort & Mixed aetiology & 33 & $56.5 \pm 15.9$ & 61 \\
\hline 38. Huang & 2014 & Cohort & Mixed aetiology & 101 & $\begin{array}{l}\text { Successful } 65 \pm 18 \\
\text { Unsuccessful } 71 \pm 16\end{array}$ & 65 \\
\hline 39. Zhang & 2014 & Cohort & $\begin{array}{l}\text { SIRS/MODS } \\
\text { (non-MODS) }\end{array}$ & 41 & 47 [34-59] & 54 \\
\hline 40. Schmidt & 2014 & Case-control $^{a}$ & $\begin{array}{l}\text { CCF and MODS } \\
\text { (literature values) }\end{array}$ & 130 & $\begin{array}{l}\text { CCF } 63 \pm 10.1 \\
\text { MODS } 62.8 \pm 10.2\end{array}$ & 63 \\
\hline 52. Tang & 2014 & Case-control & Stroke & 227 & $\begin{array}{l}\text { AF stroke } 74 \pm 12 \\
\text { Non-AF stroke } 62 \pm 15 \\
\text { Age/sex-matched controls } \\
61 \pm 10\end{array}$ & 40 \\
\hline
\end{tabular}


Table 1 Demographics and study design of studies (Continued)

\begin{tabular}{|c|c|c|c|c|c|c|}
\hline 41. Zaal & 2015 & Case-control & $\begin{array}{l}\text { ICU delirium } \\
\text { (no delirium) }\end{array}$ & 25 & $\begin{array}{l}\text { ICU delirium } 67 \pm 12 \\
\text { No ICU delirium } 57 \pm 16\end{array}$ & 72 \\
\hline 42. Hammash & 2015 & Cohort & Weaning & 35 & $53.3 \pm 14.6$ & 66 \\
\hline 53. Nagaraj & 2016 & Case series $^{a}$ & Not specified & 40 & $56.3 \pm 16.8$ & 62.5 \\
\hline
\end{tabular}

Reference for each paper is shown before first author (first column)

CCF congestive cardiac failure, MODS multiple organ dysfunction syndrome, SIRS systemic inflammatory response syndrome, SOFA sequential organ failure assessment

Retrospective analysis

matched healthy volunteers, non-critically ill patients with established cardiovascular disease or HRV values derived from the literature. External validity (as adjudged by the Down and Black assessment tool) was poor, with the majority of studies achieving a score of 1 .

\section{Risk of bias assessment}

We found recurring potential sources of bias in study design, with 19 (61\%) studies failing to report whether HRV data analysers were masked to the patient condition/outcome (Additional file 1). Only one study performed a power calculation [41].

\section{Data acquisition and preparation}

Details on short-term recordings, including source of heart rate periods [54, 55], duration of recordings, epochs used for analysis and patient position [56] were variable or not reported. Fourteen (45\%) studies did not describe the sampling frequency of recordings; four (13\%) studies used sampling rates below the recommended $250 \mathrm{~Hz}$ [15].

ECG recording in the critically ill population is frequently contaminated by electrical and physiological artefacts. Thus, detailing methods to detect artefact (manual or automated) and its management (segment selection, deletion or interpolation) is important for data interpretation [57]. Fourteen (45\%) studies reported automated and/or manual editing of the raw ECG to remove artefact by replacing the missing data with cubic spline or linear interpolation methods. In keeping with guidelines, the majority of studies used interpolation methods as opposed to deletion of abnormal beats to avoid a loss of information [15].

\section{HRV analysis}

Measurement protocols, processing and reporting of HRV data are summarised in Table 3.

A minority of studies $(14 ; 45 \%)$ reported both frequency and time domain data (Table 3). A minority of studies $(9 ; 29 \%)$ reported frequency data in normalised units together with absolute values, in keeping with established recommendations. Summary values for commonly reported HRV parameters revealed a wide range of non-normally distributed data for each (Additional file 1: Table S3). Reporting and/or adjustment for heart rate and respiratory rate, which dramatically alter both high and low frequency spectral components [58] was inconsistent between studies. A small majority of studies (17; 55\%) reported average heart rate, whilst a minority $(6 ; 19 \%)$ adjusted for, or reported, respiratory rate during data acquisition. 
Table 2 Study objectives and key findings

\begin{tabular}{|c|c|c|c|}
\hline Author & Year & Study objectives & Key findings \\
\hline Annane & 1999 & $\begin{array}{l}\text { Compare HRV between sepsis, septic } \\
\text { shock and healthy volunteers }\end{array}$ & $\begin{array}{l}\text { TP, LF, LFnu, LF/HF lower in septic } \\
\text { shock vs sepsis }\end{array}$ \\
\hline Korach & 2001 & $\begin{array}{l}\text { Effects of sepsis, age, sedation, } \\
\text { catecholamines and illness severity } \\
\text { on sympathovagal balance (LF/HF) }\end{array}$ & $\begin{array}{l}\text { LF/HF ratio }<1.5 \text { was associated with } \\
\text { sepsis and mortality }\end{array}$ \\
\hline Barnaby & 2002 & Assess if HRV can predict sepsis severity & $\begin{array}{l}\text { Negative correlation between LFnu, } \\
\text { LF/HF and SOFA score }\end{array}$ \\
\hline Pontet & 2003 & Assess if HRV can predict MODS in sepsis & $\begin{array}{l}\text { Low LF and RMSSD associated with } \\
\text { MODS }\end{array}$ \\
\hline Shen & 2003 & $\begin{array}{l}\text { Assess changes in cardiac autonomic } \\
\text { activity during weaning from } \\
\text { mechanical ventilation }\end{array}$ & $\begin{array}{l}\text { HF, LF and TP decreased in } \\
\text { unsuccessful group during } \\
\text { spontaneous breathing trial }\end{array}$ \\
\hline Schmidt & 2005 & $\begin{array}{l}\text { Effects of MODS, age, sedation, } \\
\text { catecholamines, mechanical ventilation } \\
\text { on HRV } \\
\text { Assess if HRV can predict mortality in } \\
\text { MODS }\end{array}$ & $\begin{array}{l}\text { Time and frequency domain reduced } \\
\text { in MODS } \\
\text { HRV indices affected by mechanical } \\
\text { ventilation but not age, sedation or } \\
\text { catecholamines } \\
\text { LnVLF associated with 28-day survival. }\end{array}$ \\
\hline Papaioannou & 2006 & $\begin{array}{l}\text { Assess if HRV associated with disease } \\
\text { severity and mortality }\end{array}$ & $\begin{array}{l}\text { LF/HF ratio negatively correlated } \\
\text { with SOFA score }\end{array}$ \\
\hline Bourgault & 2006 & Effects of endotracheal suction on HRV & $\begin{array}{l}\text { No significant differences found in } \\
\text { HRV indices between closed or open } \\
\text { suctioning }\end{array}$ \\
\hline Chen & 2007 & Assess if HRV can predict sepsis severity & $\begin{array}{l}\text { Septic shock associated lower LF, } \\
\text { LFnu, LF/HF, and higher RMSSD, HF, } \\
\text { HFnu }\end{array}$ \\
\hline Passariello & 2007 & $\begin{array}{l}\text { Assess if HRV can predict ischaemic } \\
\text { sudden cardiac death }\end{array}$ & $\begin{array}{l}\text { SDNN decreases shortly before } \\
\text { ischaemic sudden death }\end{array}$ \\
\hline Chen & 2008 & $\begin{array}{l}\text { Assess if HRV can predict 28-day } \\
\text { mortality }\end{array}$ & $\begin{array}{l}\text { Low SDNN, TP, VLF, LF and LF/HF } \\
\text { associated with increased 28-day } \\
\text { mortality }\end{array}$ \\
\hline Aboab & 2008 & $\begin{array}{l}\text { Assess effect of steroids on HRV in } \\
\text { patients with sepsis }\end{array}$ & $\begin{array}{l}\text { LF, LFnu, LF/HF lower in septic shock. } \\
\text { Corticosteroids helped increase LFnu } \\
\text { values in adrenal insufficiency group. }\end{array}$ \\
\hline Nogueira & 2008 & $\begin{array}{l}\text { Assess relationship between HRV, } \\
\text { markers of myocardial damage and } \\
\text { free fatty acids in sepsis }\end{array}$ & $\begin{array}{l}\text { Low LF, HF and LF/HF associated with } \\
\text { mortality }\end{array}$ \\
\hline Papaioannou & 2009 & $\begin{array}{l}\text { Assess relationship between HRV and } \\
\text { biomarkers of inflammation (CRP, IL-6, } \\
\text { IL-10) in patients with sepsis }\end{array}$ & $\begin{array}{l}\text { There is a negative correlation } \\
\text { between LFnu, LF/HF and CRP, IL-6, } \\
\text { IL-10, SOFA score }\end{array}$ \\
\hline Tiainen & 2009 & $\begin{array}{l}\text { Assess if HRV changes (and has } \\
\text { prognostic ability) with therapeutic } \\
\text { cooling of resuscitated cardiac arrest } \\
\text { patients }\end{array}$ & $\begin{array}{l}\text { Higher SDNN, SDANN, TP, LF, HF in } \\
\text { the first } 48 \mathrm{~h} \text { of cooling. SDNN } \\
>100 \text { ms predicts better neurological } \\
\text { outcome }\end{array}$ \\
\hline Schmidt & 2010 & $\begin{array}{l}\text { To assess if ACE-I therapy affects short } \\
\text { ( } 28 \text {-day) and long ( } 365 \text {-day) mortality } \\
\text { in patients with MODS }\end{array}$ & $\begin{array}{l}\text { ACE-I associated with preserved VLF, } \\
\text { LF, HF, TP and survival (28-day and } \\
365 \text {-day) }\end{array}$ \\
\hline Kasaoka & 2010 & $\begin{array}{l}\text { To trial a real-time HRV measurement } \\
\text { and analysis system }\end{array}$ & $\begin{array}{l}\text { LF, HF and LF/HF higher in patients } \\
\text { spontaneously breathing compared } \\
\text { to mechanical ventilation }\end{array}$ \\
\hline Chen & 2012 & $\begin{array}{l}\text { To compare HRV between } \\
\text { post-resuscitation cardiac arrest patients } \\
\text { and patients with severe sepsis }\end{array}$ & $\begin{array}{l}\text { No significant differences in HRV } \\
\text { indices between OOHCA and Severe } \\
\text { Sepsis patients } \\
\text { Low LF, LFnu, LF/HF associated with } \\
\text { mortality }\end{array}$ \\
\hline Gomez Duque & 2012 & $\begin{array}{l}\text { To investigate the incidence of } \\
\text { cardiovascular adverse events in } \\
\text { patients with sepsis }\end{array}$ & $\begin{array}{l}\text { Deceased patients demonstrated } \\
\text { lower SDNN than survivors }\end{array}$ \\
\hline
\end{tabular}


Table 2 Study objectives and key findings (Continued)

\begin{tabular}{|c|c|c|c|}
\hline Brown & 2013 & $\begin{array}{l}\text { Assess if HRV can predict vasopressor } \\
\text { dependence at } 24 \mathrm{~h} \text { in sepsis }\end{array}$ & $\begin{array}{l}\text { Traditional HRV indices not associated } \\
\text { with vasopressor requirement after } \\
\text { controlling for HR }\end{array}$ \\
\hline Green & 2013 & $\begin{array}{l}\text { Association of HRV and illness severity } \\
\text { in MODS }\end{array}$ & $\begin{array}{l}\text { Low LFnu and LF/HF associated with } \\
\text { increased MODS }\end{array}$ \\
\hline Wieske & 2013 & $\begin{array}{l}\text { Relationship between autonomic } \\
\text { dysfunction (HRV) and ICU-acquired } \\
\text { weakness }\end{array}$ & $\begin{array}{l}\text { Artefacts, mechanical ventilation, } \\
\text { sedation, catecholamines and heart } \\
\text { rate all associated with TP } \\
\% \text { artefacts were associated with TP } \\
\text { and LF/HF } \\
\text { No association between HRV and } \\
\text { ICU-acquired weakness }\end{array}$ \\
\hline Wieske & 2013 & $\begin{array}{l}\text { Compare different autonomic function } \\
\text { tests in critically unwell patients } \\
\text { (CFT, SWT and HRV) }\end{array}$ & $\begin{array}{l}\text { Only HRV tests associated with } \\
\text { SOFA score }\end{array}$ \\
\hline Bradley & 2013 & $\begin{array}{l}\text { Impact of sedation and sedation } \\
\text { interruptions on HRV }\end{array}$ & $\begin{array}{l}\text { SDNN, RMSSD and HF all increased } \\
\text { during sedation interruption (more } \\
\text { pronounced in less unwell patients) }\end{array}$ \\
\hline Huang & 2014 & $\begin{array}{l}\text { Assess if HRV associated with weaning } \\
\text { success or failure }\end{array}$ & $\begin{array}{l}\text { Reduction in TP during SBT } \\
\text { associated with failure }\end{array}$ \\
\hline Tang & 2014 & $\begin{array}{l}\text { Assess if HRV predicts outcome in ICU } \\
\text { stroke patients }\end{array}$ & $\begin{array}{l}\text { Traditional HRV indices were unable } \\
\text { to predict outcome }\end{array}$ \\
\hline Zhang & 2014 & $\begin{array}{l}\text { Asses if HRV can predict infected } \\
\text { pancreatic necrosis or MODS in patients } \\
\text { with severe acute pancreatitis }\end{array}$ & $\begin{array}{l}\text { Low LFnu, LF/HF and high HFnu } \\
\text { associated with increased MODS } \\
\text { and mortality }\end{array}$ \\
\hline Schmidt & 2014 & $\begin{array}{l}\text { Assess relationship between HRV and } \\
\text { illness severity in CCF and MODS }\end{array}$ & $\begin{array}{l}\text { MODS patients demonstrated lower } \\
\text { HRV indices in all parameters } \\
\text { compared to CCF patients. }\end{array}$ \\
\hline Zaal & 2015 & $\begin{array}{l}\text { To assess if HRV is abnormal in patients } \\
\text { with ICU delirium. }\end{array}$ & $\begin{array}{l}\text { No association between HRV and } \\
\text { delirium found }\end{array}$ \\
\hline Hammash & 2015 & $\begin{array}{l}\text { Assess relationship between HRV and } \\
\text { incidence of dysrhythmias during } \\
\text { weaning }\end{array}$ & $\begin{array}{l}\text { LF was higher during spontaneous } \\
\text { breathing than during controlled } \\
\text { mechanical ventilation. }\end{array}$ \\
\hline Nagaraj & 2016 & $\begin{array}{l}\text { Assess if sedation levels can be } \\
\text { classified by HRV algorithms }\end{array}$ & $\begin{array}{l}\text { Algorithms using composite } \\
\text { measures of HRV may discriminate } \\
\text { between levels of sedation in ICU } \\
\text { patients }\end{array}$ \\
\hline
\end{tabular}

$A C E-I$ angiotensin-converting enzyme inhibitor, CCF congestive cardiac failure, CFT cold face test, CRP C-reactive protein, HF high frequency, HFnu high frequency normalised unit, HRV heart rate variability, IL-6 interleukin 6, IL-10 interleukin 10, LF low frequency, LFnu low frequency normalised unit, MODS multiple organ dysfunction, RMSSD root mean square of successive differences, SOFA sequential organ failure assessment, SBT spontaneous breathing trial, SWT skin wrinkle test, TP total power, VLF very low frequency, LnVLF natural logarithm of very low frequency

\section{Pharmacologic and clinical interventions}

Studies varied in their exclusion criteria and reporting of potential confounding factors including age, gender, body mass index [59], common comorbidities [60-63], drug therapy [64-68] and/or ICU interventions (Tables 4 and 5). Exclusion criteria used and comorbidities/drugs are summarised in Additional file 1. A minority of studies (12; $39 \%$ ) excluded patients with chronic comorbidities that are commonly associated with autonomic dysfunction. Reporting of drugs that directly affect autonomic function was highly variable across studies. A majority of studies $(25 ; 81 \%)$ did not detail drug therapy. Around $22 \%$ studies did not report the use of mechanical ventilation, and more than $25 \%$ failed to report whether sedation and/or vasoactive drugs were used at the time of HRV recordings. 


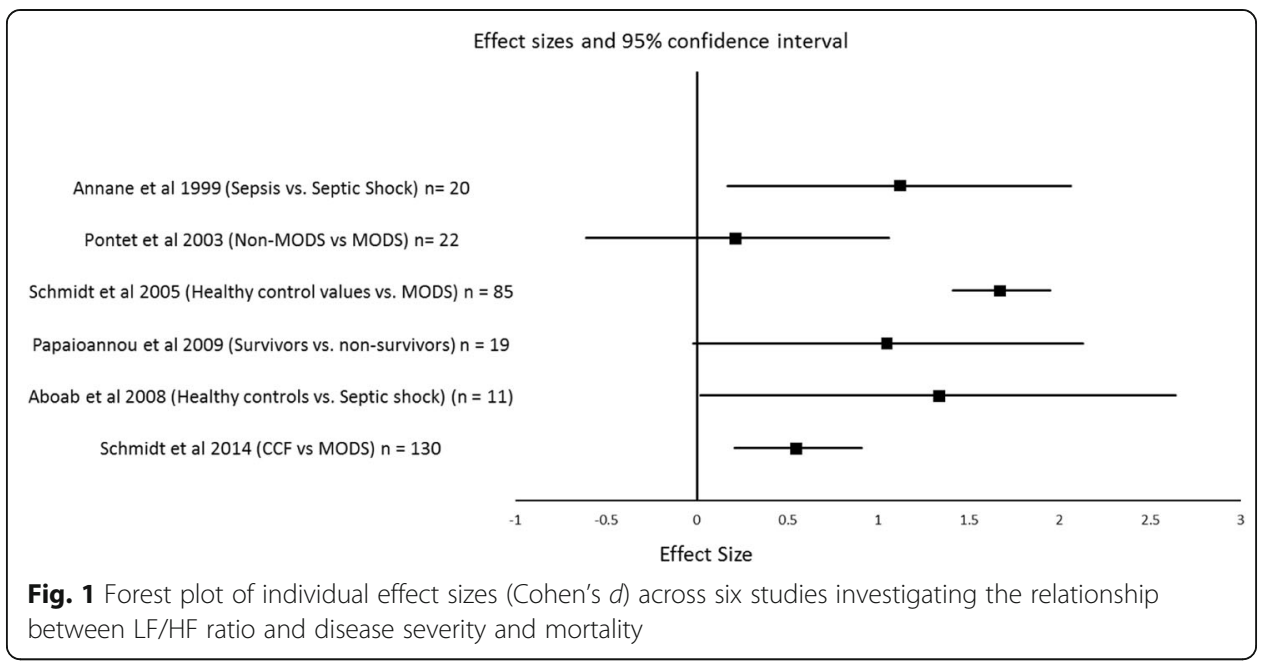

\section{Discussion}

This review is the first to systematically explore how HRV analyses are undertaken and/or reported in critically ill patients. Despite a wealth of laboratory and translational data suggesting that HRV may offer diagnostic and prognostic utility, significant heterogeneity in methodology between HRV articles precluded comparisons across studies and meta-analysis. Our review identifies several areas that require greater scrutiny in future, highlighting the need to develop consensus guidelines that are relevant and tailor-made for the challenges faced by researchers in critical care medicine.

Well-recognised technical, physiologic and clinical factors impact on the measurement, and interpretation of HRV $[69,70]$. We found highly variable practice in three key technical areas. Low sampling rates $(<250 \mathrm{~Hz})$ impair the precise detection of the $\mathrm{R}$ wave fiducial point in the ECG waveform, which consequently affects the power spectrum [15]. This is particularly relevant for studies that derived $\mathrm{R}-\mathrm{R}$ intervals from arterial pressure waveform analysis [20, 47], since non-neural respiratory influences (e.g. changes in ventricular mechanics) differentially affect mechanical pulse waves and electrical $R$ waves [55]. Manual inspection of the raw ECG to identify artefact is preferred to automated methods to avoid the introduction of false frequency components into the power spectrum [57]. The variable (or unstated) masking of HRV analysers to clinical data also introduces potential significant bias.

From a physiologic perspective, reporting and/or adjustment for heart rate and respiratory rate was inconsistent between studies, with heart rate frequently not reported. Across species with highly variable heart rates, HRV appears to be largely attributable to incident heart rate. If heart rate is not taken into account, erroneous conclusions regarding HRV are likely since differences may merely reflect lower heart rate [12]. This is particularly of relevance to hemodynamically unstable critically ill patients, in whom heart rate may rapidly change. Similarly, increases in respiratory frequency and tidal volume affect both high and low frequency spectral components [58]. Hence, standardised criteria for ventilatory and heart rate reporting are required for the interpretation of HRV data between studies (and hence, potentially, meta-analysis).

From a clinical perspective, HRV parameters are influenced strongly by age, gender, functional capacity and chronic comorbidities. Whilst all studies estimated severity of 
Table 3 Procedures for measurement, processing and reporting of HRV

\begin{tabular}{|c|c|c|c|c|c|c|}
\hline Author & Year & $\begin{array}{l}\text { Recording protocol } \\
\text { (duration/position/time) }\end{array}$ & Monitor & $\begin{array}{l}\text { Sampling } \\
\text { frequency } \\
(\mathrm{Hz})\end{array}$ & $\begin{array}{l}\text { Management } \\
\text { of artefact }\end{array}$ & Data presented \\
\hline Annane & 1999 & $5 \mathrm{~min} /-/-$ & PRV & 500 & Interpolation & TP, LF, HF, LF/HF, Lfnu, Hfnu \\
\hline Korach & 2001 & 30 min supine/0800-1200 & ECG & 5 & Interpolation & Lfnu, Hfnu, LF/HF \\
\hline Barnaby & 2002 & $5 \mathrm{~min} /-/-$ & ECG & - & Interpolation & TP, LF, HF, Lfnu, Hfnu, LF/HF \\
\hline Pontet & 2003 & $10 \mathrm{~min} / \mathrm{supine} / 2100-2300$ & ECG & $>500$ & Interpolation & $\begin{array}{l}\text { SDNN, RMSSD, LF, HF, Lfnu, } \\
\text { Hfnu, LF/HF }\end{array}$ \\
\hline Shen & 2003 & $\begin{array}{l}90 \mathrm{~min} / \mathrm{semi} \text { recumbent/ } \\
1000-1400\end{array}$ & ECG & - & Interpolation & $\begin{array}{l}\text { TP, LnLF, LnHF, Lfnu, Hfnu, } \\
\text { LF/HF }\end{array}$ \\
\hline Schmidt & 2005 & 24 hours & ECG & 256 & Interpolation & $\begin{array}{l}\text { SDNN, SDANN, RMSSD, } \\
\text { pNN50, VLF, LF, HF, LF/HF }\end{array}$ \\
\hline Papaioannou & 2006 & 10 min/supine/morning & ECG & 250 & $\begin{array}{l}\text { Segment } \\
\text { selection }\end{array}$ & LF/HF \\
\hline Bourgault & 2006 & 20 min/-/day and night & ECG & 1000 & - & $L F, H F, L F / H F, T P$ \\
\hline Chen & 2007 & $\begin{array}{l}10 \mathrm{~min} / \text { supine/day and } \\
\text { night }\end{array}$ & ECG & - & Interpolation & $\begin{array}{l}\text { RMSSD, TP, LF, HF, Lfnu, } \\
\text { Hfnu, LF/HF }\end{array}$ \\
\hline Passariello & 2007 & $24 \mathrm{~h}$ & ECG & - & - & $\begin{array}{l}\text { SDNN, SDANN, pNN50, } \\
\text { RMSSD }\end{array}$ \\
\hline Chen & 2008 & $\begin{array}{l}10 \mathrm{~min} / \text { supine/day and } \\
\text { night }\end{array}$ & ECG & - & Interpolation & $\begin{array}{l}\text { SDNN, RMSSD, TP, LF, HF, } \\
\text { Lfnu, Hfnu, LF/HF }\end{array}$ \\
\hline Aboab & 2008 & 5 min/supine/- & PRV & - & Interpolation & TP, Lfnu, Hfnu, LF/HF \\
\hline Nogueira & 2008 & $30 \mathrm{~min} / \mathrm{supine} /$ morning & ECG & - & - & $L F, H F, L F / H F$ \\
\hline Papaioannou & 2009 & $10 \mathrm{~min} /-/-$ & ECG & 250 & $\begin{array}{l}\text { Segment } \\
\text { selection }\end{array}$ & SDNN, Lfnu, Hfnu, LF/HF \\
\hline Tiainen & 2009 & $24 \mathrm{~h}$ & ECG & - & - & SDNN, SDANN, TP, LF, HF, \\
\hline Schmidt & 2010 & $24 \mathrm{~h}$ & ECG & 256 & Interpolation & $\begin{array}{l}\text { LnTP, LnVLF, LnHF, LnLF, } \\
\text { LF/HF }\end{array}$ \\
\hline Kasaoka & 2010 & 5 min/supine/- & ECG & - & - & LnLF, LnHF, LF/HF \\
\hline Chen & 2012 & $\begin{array}{l}10 \mathrm{~min} / \text { supine/day and } \\
\text { night }\end{array}$ & ECG & - & Interpolation & $\begin{array}{l}\text { SDNN, TP, VLF, LF, HF, Hfnu, } \\
\text { Lfnu, LF/HF }\end{array}$ \\
\hline Gomez Duque & 2012 & $24 \mathrm{~h}$ & ECG & - & - & SDNN, PNN50 \\
\hline Brown & 2013 & $6 \mathrm{~h} /-1-$ & ECG & 500 & Deletion & $\begin{array}{l}\text { SDNN, pNN50, Lfnu, Hfnu, } \\
\text { LF/HF }\end{array}$ \\
\hline Green & 2013 & $24 \mathrm{~h}$ & ECG & 125 & Deletion & $\begin{array}{l}\text { SDNN, RMSSD, Lfnu, Hfnu, } \\
\text { LF/HF }\end{array}$ \\
\hline Wieske & 2013 & $5 \mathrm{~min} /-/-$ & ECG & 250 & Interpolation & $\mathrm{HR}, \mathrm{TP}, \mathrm{LF} / \mathrm{HF}$ \\
\hline Wieske & 2013 & 5 min/supine/- & ECG & 250 & Deletion & $L F, H F, L f n u, H f n u, L F / H F$ \\
\hline Bradley & 2013 & $24 \mathrm{~h}$ & ECG & 125 & Deletion & SDNN, RMSSD, LF, HF, LF/HF \\
\hline Huang & 2014 & $\begin{array}{l}5 \mathrm{~min} / \text { semi-recumbent/ } \\
0800-1200\end{array}$ & ECG & - & - & $\begin{array}{l}\text { LnTP, LnVLF, Hfnu, Lfnu, } \\
\text { LF/HF }\end{array}$ \\
\hline Tang & 2014 & $60 \mathrm{~min} /-/-$ & $\mathrm{ECH}$ & 512 & - & SDNN, RMSSD, LF, HF, LF/HF \\
\hline Zhang & 2014 & $5 \mathrm{~min} /-/ 0900-1100$ & ECG & - & Deletion & $\begin{array}{l}\text { SDNN, RMSSD, TP, VLF, LF, } \\
\text { HF, Lfnu, Hfnu, LF/HF }\end{array}$ \\
\hline Schmidt & 2014 & $24 \mathrm{~h}$ & ECG & 256 & Interpolation & $\begin{array}{l}\text { SDNN, SDANN, SDNNi, } \\
\text { RMSSD, pNN50, VLF, LF, HF, } \\
\text { LnLF, LnHF, LF/HF }\end{array}$ \\
\hline Zaal & 2015 & $15 \mathrm{~min} / \mathrm{supine}, 0800-1700$ & ECG & 500 & $\begin{array}{l}\text { Segment } \\
\text { selection }\end{array}$ & LnLF, LnHF, Hfnu, LF/HF \\
\hline Hammash & 2015 & $24 \mathrm{~h}$ & ECG & - & Interpolation & $V L F, H F, L F$ \\
\hline Nagaraj & 2016 & 24 h (5 min epochs) & ECG & 240 & Thresholding & $\begin{array}{l}\text { SDNN, RMSSD, VLF, LF, HF, } \\
\text { LF/HF, LFnu, HFnu }\end{array}$ \\
\hline
\end{tabular}

ECG electrocardiogram, HF high frequency, HFnu high frequency normalised unit, LF low frequency, LFnu low frequency normalised unit, $L n$ natural logarithm, $p N N 50$ percentage of normal-normal intervals $>50 \mathrm{~ms}, P R V$ pulse rate variability, RMSSD root mean square of successive differences, SDANN standard deviation of average normalnormal intervals, SDNN standard deviation of normal-normal intervals, TP total power 
Table 4 Reporting of potential clinical confounders

\begin{tabular}{|c|c|c|c|c|c|c|c|c|}
\hline Author & Year & Comorbidities & Drugs & $\begin{array}{l}\text { Mechanical } \\
\text { ventilation } \\
\text { (\% patients) }\end{array}$ & $\begin{array}{l}\text { Sedation } \\
\text { (\% patients) }\end{array}$ & $\begin{array}{l}\text { Catecholamines } \\
\text { (\% patients) }\end{array}$ & Feeding & $\begin{array}{l}\text { HR/RR } \\
\text { reportec }\end{array}$ \\
\hline Annane & 1999 & Excluded & - & $100 \%$ & $0 \%$ & $0 \%$ & - & $\mathrm{HR} / \mathrm{RR}$ \\
\hline Korach & 2001 & - & - & $41.5 \%$ & $19.5 \%$ & $12.20 \%$ & - & - \\
\hline Barnaby & 2002 & - & - & $0 \%$ & - & $0 \%$ & - & $\mathrm{HR} / \mathrm{RR}$ \\
\hline Pontet & 2003 & Excluded & Excluded & $38.5 \%$ & - & $17.90 \%$ & - & $H R$ \\
\hline Shen & 2003 & + & + & $100 \%$ & $0 \%$ & $0 \%$ & - & $\mathrm{HR} / \mathrm{RR}$ \\
\hline Schmidt & 2005 & - & - & $71 \%$ & $61 \%$ & $62 \%$ & - & - \\
\hline Papaioannou & 2006 & + & - & - & + & - & - & - \\
\hline Bourgault & 2006 & Excluded & Excluded & $100 \%$ & $33 \%$ & $0 \%$ & - & $H R$ \\
\hline Chen & 2007 & Excluded/+ & - & - & - & $0 \%$ & - & $\mathrm{HR} / \mathrm{RR}$ \\
\hline Passriello & 2007 & + & + & - & - & - & - & $H R$ \\
\hline Chen & 2008 & + & - & $0 \%$ & - & - & - & $H R$ \\
\hline Aboab & 2008 & Excluded & - & $100 \%$ & $80.9 \%$ & $100 \%$ & - & $H R$ \\
\hline Nogueira & 2008 & Excluded & - & $100 \%$ & - & $100 \%$ & - & $\mathrm{RR}$ \\
\hline Papaioannou & 2009 & - & Excluded & $100 \%$ & $100 \%$ & - & - & - \\
\hline Tiainen & 2009 & + & - & $100 \%$ & $100 \%$ & $87 \%$ & - & $H R$ \\
\hline Schmidt 0 & 2010 & + & - & $88 \%$ & $89 \%$ & $74 \%$ & - & - \\
\hline Kasaoka 1 & 2010 & - & - & $100 \%$ & $100 \%$ & - & - & - \\
\hline Chen & 2012 & + & - & $\begin{array}{l}\text { OHCA } 100 \% \\
\text { SS + MV 100\%, } \\
\text { SS 0\%, S 0\% }\end{array}$ & $\begin{array}{l}\text { OHCA } 81 \\
\text { SS + MV 63\%, } \\
\text { SS 59\%, S 0\% }\end{array}$ & $\begin{array}{l}\text { OHCA } 100 \% \\
\text { SS + MV 9\%, } \\
\text { SS } 18.8 \%, \text { S } 0 \%\end{array}$ & - & $H R$ \\
\hline Gomez Duque & 2012 & Excluded/+ & - & - & - & $72 \%$ & - & - \\
\hline Brown & 2013 & - & - & - & - & $63 \%$ & - & $H R$ \\
\hline Green & 2013 & - & - & $90.90 \%$ & + & $78.80 \%$ & - & $\mathrm{HR}$ \\
\hline Wieske & 2013 & Excluded/+ & + & + & + & + & - & $H R$ \\
\hline Wieske & 2013 & Excluded/+ & - & $100 \%$ & - & - & - & - \\
\hline Bradley & 2013 & - & - & + & + & + & - & $H R$ \\
\hline Huang & 2014 & Excluded/+ & Excluded/+ & $100 \%$ & - & - & - & $\mathrm{RR}$ \\
\hline Zhang & 2014 & - & - & - & - & $12 \%$ & - & - \\
\hline Schmidt & 2014 & - & + & $89.2 \%$ & $72.3 \%$ & $72.3 \%$ & - & $H R$ \\
\hline Tang & 2014 & + & + & - & - & - & - & $H R$ \\
\hline Zaal & 2015 & Excluded & Excluded & $60 \%$ & $20 \%$ & $0 \%$ & - & - \\
\hline Hammash & 2015 & Excluded/+ & - & $100 \%$ & - & - & - & - \\
\hline Nagaraj & 2016 & - & - & $100 \%$ & $100 \%$ & - & - & $H R$ \\
\hline
\end{tabular}

Excluded refers to specific comorbidities or drugs were part of exclusion criteria of study

$H R$ heart rate, $R R$ respiratory rate, + reported but proportion of patients not provided, - not reported

illness, the most frequently employed-Acute Physiology and Chronic Health Evaluation II (APACHE-II) - are limited in capturing information about chronic comorbid disease that are over-represented in the critical care medicine population. For example, diabetes mellitus, a common condition associated with cardiac autonomic neuropathy, is not captured by this type of assessment [60]. Typically, chronic conditions at the severe end of the disease spectrum are included (e.g. APACHE-II score only includes severe heart failure ( $\geq$ NYHA class 3 ). However, HRV parameters have been found to be abnormal in early cases of chronic disease, including preserved ejection fraction, coronary artery disease, chronic kidney disease and hypertension [60-63]. Although some studies have considered these factors, serial measures or dynamic autonomic challenges offer a potentially more insightful and individualised approach to 
Table 5 Reporting of potential confounders

\begin{tabular}{|c|c|c|c|c|c|c|c|c|}
\hline Author & Year & Comorbidities & Drugs & $\begin{array}{l}\text { Mechanical } \\
\text { ventilation } \\
\text { (\% patients) }\end{array}$ & $\begin{array}{l}\text { Sedation } \\
\text { (\% patients) }\end{array}$ & $\begin{array}{l}\text { Catecholamines } \\
\text { (\% patients) }\end{array}$ & Feeding & $\begin{array}{l}\mathrm{HR} / \mathrm{RR} \\
\text { reported }\end{array}$ \\
\hline Annane [17] & 1999 & Excluded & - & $100 \%$ & $0 \%$ & $0 \%$ & - & $\mathrm{HR} / \mathrm{RR}$ \\
\hline Korach [18] & 2001 & - & - & $41.5 \%$ & $19.5 \%$ & $12.20 \%$ & - & - \\
\hline Barnaby [19] & 2002 & - & - & $0 \%$ & - & $0 \%$ & - & $\mathrm{HR} / \mathrm{RR}$ \\
\hline Pontet [20] & 2003 & Excluded & Excluded & $38.5 \%$ & - & $17.90 \%$ & - & $H R$ \\
\hline Shen [21] & 2003 & + & + & $100 \%$ & $0 \%$ & $0 \%$ & - & $\mathrm{HR} / \mathrm{RR}$ \\
\hline Schmidt [22] & 2005 & - & - & $71 \%$ & $61 \%$ & $62 \%$ & - & - \\
\hline Papaioannou [23] & 2006 & + & - & - & + & - & - & - \\
\hline Bourgault [24] & 2006 & Excluded & Excluded & $100 \%$ & $33 \%$ & $0 \%$ & - & $H R$ \\
\hline Chen [25] & 2007 & Excluded/+ & - & - & - & $0 \%$ & - & $\mathrm{HR} / \mathrm{RR}$ \\
\hline Passriello & 2007 & + & + & - & - & - & - & $H R$ \\
\hline Chen [26] & 2008 & + & - & $0 \%$ & - & - & - & $H R$ \\
\hline Aboab [27] & 2008 & Excluded & - & $100 \%$ & $80.9 \%$ & $100 \%$ & - & $H R$ \\
\hline Nogueira [28] & 2008 & Excluded & - & $100 \%$ & - & $100 \%$ & - & $\mathrm{RR}$ \\
\hline Papaioannou [29] & 2009 & - & Excluded & $100 \%$ & $100 \%$ & - & - & - \\
\hline Tiainen & 2009 & + & - & $100 \%$ & $100 \%$ & $87 \%$ & - & $\mathrm{HR}$ \\
\hline Schmidt [30] & 2010 & + & - & $88 \%$ & $89 \%$ & $74 \%$ & - & - \\
\hline Kasaoka [31] & 2010 & - & - & $100 \%$ & $100 \%$ & - & - & - \\
\hline Chen [32] & 2012 & + & - & $\begin{array}{l}\text { OHCA } 100 \% \\
\text { SS + MV } 100 \% \\
\text { SS 0\%, S 0\% }\end{array}$ & $\begin{array}{l}\text { OHCA } 81 \\
\text { SS + MV 63\% } \\
\text { SS 59\%, S 0\% }\end{array}$ & $\begin{array}{l}\text { OHCA } 100 \% \\
\text { SS + MV 9\%, } \\
\text { SS } 18.8 \%, \text { S } 0 \%\end{array}$ & - & $H R$ \\
\hline Gomez Duque [33] & 2012 & Excluded/+ & - & - & - & $72 \%$ & - & - \\
\hline Brown [34] & 2013 & - & - & - & - & $63 \%$ & - & $\mathrm{HR}$ \\
\hline Green [35] & 2013 & - & - & $90.90 \%$ & + & $78.80 \%$ & - & $H R$ \\
\hline Wieske [36] & 2013 & Excluded/+ & + & + & + & + & - & $\mathrm{HR}$ \\
\hline Wieske [37] & 2013 & Excluded/+ & - & $100 \%$ & - & - & - & - \\
\hline Bradley [38] & 2013 & - & - & + & + & + & - & $\mathrm{HR}$ \\
\hline Huang [39] & 2014 & Excluded/+ & Excluded/+ & $100 \%$ & - & - & - & $\mathrm{RR}$ \\
\hline Zhang [40] & 2014 & - & - & - & - & $12 \%$ & - & - \\
\hline Schmidt [41] & 2014 & - & + & $89.2 \%$ & $72.3 \%$ & $72.3 \%$ & - & $H R$ \\
\hline Tang & 2014 & + & + & - & - & - & - & $\mathrm{HR}$ \\
\hline Zaal [42] & 2015 & Excluded & Excluded & $60 \%$ & $20 \%$ & $0 \%$ & - & - \\
\hline Hammash [43] & 2015 & Excluded/+ & - & $100 \%$ & - & - & - & - \\
\hline Nagaraj & 2016 & - & - & $100 \%$ & $100 \%$ & - & - & $\mathrm{HR}$ \\
\hline
\end{tabular}

Excluded refers to specific comorbidities or drugs were part of exclusion criteria of study

$H R$ heart rate, $R R$ respiratory rate, + reported but proportion of patients not provided, - not reported

assessing HRV. Novel HRV parameters that can be captured within the first few minutes of critical illness, such as deceleration capacity of heart rate [71], may mitigate the need for refining the use of more traditional time and frequency domain measures. For mechanistic studies investigating whether changes in autonomic parameters correlate with, or precede, pathologic events, targeting clinical scenarios where multiple, complementary baseline autonomic measures $[72,73]$ can be made before critical illness develops may be optimal [74]. Studies where basal autonomic function can be captured, including elective surgery [73-76] and oncologic sepsis [48, 49], may provide particularly powerful mechanistic insights since autonomic changes can be individualised and referenced to pre-insult normal, or pre-existing, dysfunction. Several studies have highlighted that HRV values in critical care medicine are similar to those found in 
common cardiovascular pathologic conditions [74, 75, 77]; this highlights the need for individualised patient data in order to rule out that autonomic dysfunction is not a precursor of critical illness, rather than merely a biomarker.

Commonly used anti-arrhythmic drugs, anti-hypertensive drugs, statins, metformin and inhaled bronchodilators have all been associated with changes in HRV parameters [60-63]. However, the lack of reporting on medications that critically ill patients received reduces the mechanistic insight afforded by this approach, particularly given the strong correlation between HRV and morbidity/mortality appears to be largely attributable to incident heart rate. Similarly, the majority of studies in this review failed to consistently report on the use of common critical care interventions. This may explain why conflicting conclusions over how variety of features of critical illness may affect HRV. Continuous enteral or parenteral nutrition are both associated with a reduction in time domain HRV measures indicative of parasympathetic cardiac modulation [67]. However, we did not find any studies that reported on the feeding or fasting status of patients. Although a significant limitation of our study was the lack of primary source data, in any event, we could not identify a single common HRV parameter measured in all studies that enabled comparison. A further limitation is that we did not consider newer nonlinear and multiscale approaches, since very few studies incorporating these analyses have been undertaken. These approaches are also likely to be affected by the same factors that influence traditional HRV parameters [78]. Thus, in a clinical setting, further work is required to establish whether these newer approaches reduce the impact of several confounding factors we have identified in this review.

\title{
Conclusions
}

Heart rate and derived heart rate variability offers a non-invasive, inexpensive tool that may add mechanistic insights to our understanding of critical illness and also assist clinical care. However, the current interpretation of generalizable and clinically relevant values to aid clinical decisions/research is hampered by a non-standardised methodologic approach and lack of adjustment for important confounding factors. For critical care medicine to exploit recent advances in translational autonomic physiology, further high-quality prospective HRV studies underpinned by the development of consensus reporting standards relevant for critical care medicine are needed.

\section{Additional file}

Additional file 1: Clinical confounding factors. (DOCX $34 \mathrm{~kb}$ )

\begin{abstract}
Abbreviations
HRV: Heart rate variability; APACHE-II: Acute Physiology and Chronic Health Evaluation II; NYHA: New York Heart Association; ECG: Electrocardiogram; MODS: Multiple organ dysfunction syndrome
\end{abstract}

Acknowledgements

$n / a$

\section{Funding}

GLA is supported by a British Journal of Anaesthesia and Royal College of Anaesthetists Basic Science fellowship, British Oxygen Company grant from the Royal College of Anaesthetists and British Heart Foundation programme grant $(\mathrm{RG} / 14 / 4 / 30736)$. Funding bodies played no role in the design of the study and collection, analysis and interpretation of data or in writing the manuscript should be declared. 


\section{Authors' contributions}

GLA devised hypothesis/study plan. SK and AS sourced the primary material. SMM independently verified quality of studies. GLA and SK wrote the first draft of the manuscript. All authors contributed to the final revised draft.

All authors read and approved the final manuscript.

\section{Ethics approval and consent to participate}

Not applicable.

\section{Consent for publication}

Not applicable.

\section{Competing interests}

GLA is a member of the Associate editorial board of Intensive Care Medicine Experimental. GLA has received consultancy fees from Glaxo Smith Kline for unrelated purposes. The other authors declare that they have no competing interests.

\section{Publisher's Note}

Springer Nature remains neutral with regard to jurisdictional claims in published maps and institutional affiliations.

Received: 29 March 2017 Accepted: 3 July 2017

Published online: 12 July 2017

\section{References}

1. Lahiri MK, Kannankeril PJ, Goldberger JJ (2008) Assessment of autonomic function in cardiovascular disease: physiological basis and prognostic implications. J Am Coll Cardiol 51:1725-1733

2. Akselrod S, Gordon D, Ubel FA, Shannon DC, Berger AC, Cohen RJ (1981) Power spectrum analysis of heart rate fluctuation: a quantitative probe of beat-to-beat cardiovascular control. Science 213:220-222

3. Buccelletti E, Gilardi E, Scaini E, Galiuto L, Persiani R, Biondi A, Basile F, Silveri NG (2009) Heart rate variability and myocardial infarction: systematic literature review and metanalysis. Eur Rev Med Pharmacol Sci 13:299-307

4. Nolan J, Batin PD, Andrews R, Lindsay SJ, Brooksby P, Mullen M, Baig W, Flapan AD, Cowley A, Prescott RJ, Neilson JM, Fox KA (1998) Prospective study of heart rate variability and mortality in chronic heart failure: results of the United Kingdom heart failure evaluation and assessment of risk trial (UK-heart). Circulation 98:1510-1516

5. Bilchick KC, Fetics B, Djoukeng R, Fisher SG, Fletcher RD, Singh SN, Nevo E, Berger RD (2002) Prognostic value of heart rate variability in chronic congestive heart failure (Veterans Affairs' Survival Trial of Antiarrhythmic Therapy in Congestive Heart Failure). Am J Cardiol 90:24-28

6. Stuckey MI, Petrella RJ (2013) Heart rate variability in type 2 diabetes mellitus. Crit Rev Biomed Eng 41:137-147

7. Singh JP, Larson MG, Tsuji H, Evans JC, O'Donnell CJ, Levy D (1998) Reduced heart rate variability and new-onset hypertension: insights into pathogenesis of hypertension: the Framingham Heart Study. Hypertension 32:293-297

8. Ahmad S, Tejuja A, Newman KD, Zarychanski R, Seely AJ (2009) Clinical review: a review and analysis of heart rate variability and the diagnosis and prognosis of infection. Crit Care 13:232

9. Stein PK (2013) Challenges of heart rate variability research in the ICU. Crit Care Med 41:666-667

10. Nunan D, Sandercock GR, Brodie DA (2010) A quantitative systematic review of normal values for short-term heart rate variability in healthy adults. Pacing Clin Electrophysiol 33:1407-1417

11. Mazzeo AT, La Monaca E, Di Leo R, Vita G, Santamaria LB (2011) Heart rate variability: a diagnostic and prognostic tool in anesthesia and intensive care. Acta Anaesthesiol Scand 55:797-811

12. Monfredi O, Lyashkov AE, Johnsen AB, Inada S, Schneider H, Wang R, Nirmalan M, Wisloff U, Maltsev VA, Lakatta EG, Zhang H, Boyett MR (2014) Biophysical characterization of the underappreciated and important relationship between heart rate variability and heart rate. Hypertension 64:1334-1343

13. Martelli D, Silvani A, McAllen RM, May CN, Ramchandra R (2014) The low frequency power of heart rate variability is neither a measure of cardiac sympathetic tone nor of baroreflex sensitivity. Am J Physiol Heart Circ Physiol 307:H1005-1012

14. Bauer A, Malik M, Schmidt G, Barthel P, Bonnemeier H, Cygankiewicz I, Guzik P, Lombardi F, Muller A, Oto A, Schneider R, Watanabe M, Wichterle D, Zareba W (2008) Heart rate turbulence: standards of measurement, physiological interpretation, and clinical use: International Society for Holter and Noninvasive Electrophysiology Consensus. J Am Coll Cardiol 52:1353-1365

15. (1996) Heart rate variability: standards of measurement, physiological interpretation and clinical use. Task Force of the European Society of Cardiology and the North American Society of Pacing and Electrophysiology. Circulation 93: $1043-1065$

16. Moher D, Liberati A, Tetzlaff J, Altman DG (2009) Preferred reporting items for systematic reviews and metaanalyses: the PRISMA statement. J Clin Epidemiol 62:1006-1012

17. Sassi R, Cerutti S, Lombardi F, Malik M, Huikuri HV, Peng CK, Schmidt G, Yamamoto Y (2015) Advances in heart rate variability signal analysis: joint position statement by the e-Cardiology ESC Working Group and the European Heart Rhythm Association co-endorsed by the Asia Pacific Heart Rhythm Society. Europace 17:1341-1353

18. Downs SH, Black N (1998) The feasibility of creating a checklist for the assessment of the methodological quality both of randomised and non-randomised studies of health care interventions. J Epidemiol Community Health 52:377-384

19. Higgins JPT, Green S, (2011) Cochrane Handbook for Systematic Reviews of Interventions. www.handbook. cochrane.org Version 5.1.0

20. Annane D, Trabold F, Sharshar T, Jarrin I, Blanc AS, Raphael JC, Gajdos P (1999) Inappropriate sympathetic activation at onset of septic shock: a spectral analysis approach. Am J Respir Crit Care Med 160:458-465 
21. Korach M, Sharshar T, Jarrin I, Fouillot JP, Raphaël JC, Gajdos P, Annane D (2001) Cardiac variability in critically ill adults: influence of sepsis. Crit Care Med 29:1380-1385

22. Barnaby D, Ferrick K, Kaplan DT, Shah S, Bijur P, Gallagher EJ (2002) Heart rate variability in emergency department patients with sepsis. Acad Emerg Med 9:661-670

23. Pontet J, Contreras P, Curbelo A, Medina J, Noveri S, Bentancourt S, Migliaro ER (2003) Heart rate variability as early marker of multiple organ dysfunction syndrome in septic patients. J Crit Care 18:156-163

24. Shen HN, Lin LY, Chen KY, Kuo PH, Yu CJ, Wu HD, Yang PC (2003) Changes of heart rate variability during ventilator weaning. Chest 123:1222-1228

25. Schmidt H, Muller-Werdan U, Hoffmann T, Francis DP, Piepoli MF, Rauchhaus M, Prondzinsky R, Loppnow H, Buerke M, Hoyer D, Werdan K (2005) Autonomic dysfunction predicts mortality in patients with multiple organ dysfunction syndrome of different age groups. Crit Care Med 33:1994-2002

26. Papaioannou VE, Maglaveras N, Houvarda I, Antoniadou E, Vretzakis G (2006) Investigation of altered heart rate variability, nonlinear properties of heart rate signals, and organ dysfunction longitudinally over time in intensive care unit patients. J Crit Care 21:95-103, discussion 103-104

27. Nogueira AC, Kawabata V, Biselli P, Lins MH, Valeri C, Seckler M, Hoshino W, Júnior LG, Bernik MM, de Andrade Machado JB, Martinez MB, Lotufo PA, Caldini EG, Martins E, Curi R, Soriano FG (2008) Changes in plasma free fatty acid levels in septic patients are associated with cardiac damage and reduction in heart rate variability. Shock 29:342-348

28. Papaioannou VE, Dragoumanis C, Theodorou V, Gargaretas C, Pneumatikos I (2009) Relation of heart rate variability to serum levels of C-reactive protein, interleukin 6, and 10 in patients with sepsis and septic shock. J Crit Care 24:625.e621-627

29. Schmidt H, Hoyer D, Rauchhaus M, Prondzinsky R, Hennen R, Schlitt A, Carter J, Hottenrott K, Muller-Werdan U, Werdan K, Buerke M (2010) ACE-inhibitor therapy and survival among patients with multiorgan dysfunction syndrome (MODS) of cardiac and non-cardiac origin. Int J Cardiol 140:296-303

30. Kasaoka S, Nakahara T, Kawamura Y, Tsuruta R, Maekawa T (2010) Real-time monitoring of heart rate variability in critically ill patients. J Crit Care 25:313-316

31. Chen WL, Shen YS, Huang CC, Chen JH, Kuo CD (2012) Postresuscitation autonomic nervous modulation after cardiac arrest resembles that of severe sepsis. Am J Emerg Med 30:143-150

32. Gomez Duque M, Enciso Olivera C, Peña Torres E, Segura Durán OD, Nieto Estrada VH (2012) ECAIS study: inadvertent cardiovascular adverse events in sepsis. Med Intensiva 36:343-350

33. Brown SM, Tate Q, Jones JP, Knox DB, Kuttler KG, Lanspa M, Rondina MT, Grissom CK, Behera S, Mathews VJ, Morris A (2013) Initial fractal exponent of heart rate variability is associated with success of early resuscitation in patients with severe sepsis or septic shock: a prospective cohort study. J Crit Care 28:959-963

34. Green GC, Bradley B, Bravi A, Seely AJ (2013) Continuous multiorgan variability analysis to track severity of organ failure in critically ill patients. J Crit Care 28:879.e871-811

35. Wieske L, Chan Pin Yin DR, Verhamme C, Schultz MJ, van Schaik IN, Horn J (2013) Autonomic dysfunction in ICUacquired weakness: a prospective observational pilot study. Intensive Care Med 39:1610-1617

36. Wieske L, Kiszer ER, Schultz MJ, Verhamme C, van Schaik IN, Horn J (2013) Examination of cardiovascular and peripheral autonomic function in the ICU: a pilot study. J Neurol 260:1511-1517

37. Bradley BD, Green G, Ramsay T, Seely AJ (2013) Impact of sedation and organ failure on continuous heart and respiratory rate variability monitoring in critically ill patients: a pilot study. Crit Care Med 41:433-444

38. Huang CT, Tsai YJ, Lin JW, Ruan SY, Wu HD, Yu CJ (2014) Application of heart-rate variability in patients undergoing weaning from mechanical ventilation. Crit Care 18:R21

39. Zhang L, Zhou J, Ke L, Nie Y, Tong Z, Li W, Li J (2014) Role of heart rate variability in predicting the severity of severe acute pancreatitis. Dig Dis Sci 59:2557-2564

40. Schmidt H, Lotze U, Ghanem A, Anker SD, Said SM, Braun-Dullaeus R, Oltmanns G, Rose S, Buerke M, Müller-Werdan U, Werdan K, Rauchhaus M (2014) Relation of impaired interorgan communication and parasympathetic activity in chronic heart failure and multiple-organ dysfunction syndrome. J Crit Care 29:367-373

41. Zaal IJ, van der Kooi AW, van Schelven L, Oey PL, Slooter AJ (2015) Heart rate variability in intensive care unit patients with delirium. J Neuropsychiatry Clin Neurosci 27:e112-116

42. Hammash MH, Moser DK, Frazier SK, Lennie TA, Hardin-Pierce M (2015) Heart rate variability as a predictor of cardiac dysrhythmias during weaning from mechanical ventilation. Am J Crit Care 24:118-127

43. Bradley B, Green GC, Batkin I, Seely AJ (2011) Feasibility of continuous multiorgan variability analysis in the intensive care unit. J Crit Care 27:218.e9-20

44. Bourgault AM, Brown CA, Hains SM, Parlow JL (2006) Effects of endotracheal tube suctioning on arterial oxygen tension and heart rate variability. Biol Res Nurs 7:268-278

45. Chen WL, Kuo CD (2007) Characteristics of heart rate variability can predict impending septic shock in emergency department patients with sepsis. Acad Emerg Med 14:392-397

46. Chen WL, Chen JH, Huang CC, Kuo CD, Huang Cl, Lee LS (2008) Heart rate variability measures as predictors of in-hospital mortality in ED patients with sepsis. Am J Emerg Med 26:395-401

47. Aboab J, Polito A, Orlikowski D, Sharshar T, Castel M, Annane D (2008) Hydrocortisone effects on cardiovascular variability in septic shock: a spectral analysis approach. Critical Care Med 36:1481-1486

48. Ahmad S, Ramsay T, Huebsch L, Flanagan S, McDiarmid S, Batkin I, McIntyre L, Sundaresan SR, Maziak DE, Shamji FM, Hebert P, Fergusson D, Tinmouth A, Seely AJ (2009) Continuous multi-parameter heart rate variability analysis heralds onset of sepsis in adults. PLOS ONE 4:e6642

49. Bravi A, Green G, Longtin A, Seely AJ (2012) Monitoring and identification of sepsis development through a composite measure of heart rate variability. PLOS ONE 7:e45666

50. Passariello G, Peluso A, Moniello G, Maio A, Mazo S, Boccia G, Passariello N, Lettieri B, Chiefari M (2007) Effect of autonomic nervous system dysfunction on sudden death in ischemic patients with anginal syndrome died during electrocardiographic monitoring in Intensive Care Unit. Minerva Anestesiol 73:207-212

51. Tiainen M, Parikka HJ, Mäkijärvi MA, Takkunen OS, Sarna SJ, Roine RO (2009) Arrhythmias and heart rate variability during and after therapeutic hypothermia for cardiac arrest. Crit Care Med 37:403-409 
52. Tang SC, Jen HI, Lin YH, Hung CS, Jou WJ, Huang PW, Shieh JS, Ho YL, Lai DM, Wu AY, Jeng JS, Chen MF (2015) Complexity of heart rate variability predicts outcome in intensive care unit admitted patients with acute stroke. J Neurol Neurosurg Psychiatry 86:95-100

53. Nagaraj SB, McClain LM, Zhou DW, Biswal S, Rosenthal ES, Purdon PL, Westover MB (2016) Automatic classification of sedation levels in ICU patients using heart rate variability. Crit Care Med 44:e782-789

54. McKinley PS, Shapiro PA, Bagiella E, Myers MM, De Meersman RE, Grant I, Sloan RP (2003) Deriving heart period variability from blood pressure waveforms. J Appl Physiol (1985) 95:1431-1438

55. Carrasco S, Gonzalez R, Jimenez J, Roman R, Medina V, Azpiroz J (1998) Comparison of the heart rate variability parameters obtained from the electrocardiogram and the blood pressure wave. J Med Eng Technol 22:195-205

56. Montano N, Ruscone TG, Porta A, Lombardi F, Pagani M, Malliani A (1994) Power spectrum analysis of heart rate variability to assess the changes in sympathovagal balance during graded orthostatic tilt. Circulation 90:1826-1831

57. Peltola MA (2012) Role of editing of R-R intervals in the analysis of heart rate variability. Front Physiol 3:148

58. Brown TE, Beightol LA, Koh J, Eckberg DL (1993) Important influence of respiration on human R-R interval power spectra is largely ignored. J Appl Physiol (1985) 75:2310-2317

59. Antelmi I, de Paula RS, Shinzato AR, Peres CA, Mansur AJ, Grupi CJ (2004) Influence of age, gender, body mass index, and functional capacity on heart rate variability in a cohort of subjects without heart disease. Am J Cardiol 93:381-385

60. França da Silva AK, Penachini da Costa de Rezende Barbosa M, Marques Vanderlei F, Destro Christofaro DG, Marques Vanderlei LC (2016) Application of heart rate variability in diagnosis and prognosis of individuals with diabetes mellitus: systematic review. Ann Noninvasive Electrocardiol 21:223-235

61. Patel H, Ozdemir BA, Patel M, Xiao HB, Poole-Wilson PA, Rosen SD (2010) Impairment of autonomic reactivity is a feature of heart failure whether or not the left ventricular ejection fraction is normal. IntJ Cardiol 151(1):34-9. doi: 10.1016/j.jijcard.2010.04.054. Epub 2010 May 18

62. Drawz PE, Babineau DC, Brecklin C, He J, Kallem RR, Soliman EZ, Xie D, Appleby D, Anderson AH, Rahman M, Investigators CS (2013) Heart rate variability is a predictor of mortality in chronic kidney disease: a report from the CRIC Study. Am J Nephrol 38:517-528

63. Pagani M, Lucini D (2001) Autonomic dysregulation in essential hypertension: insight from heart rate and arterial pressure variability. Auton Neurosci 90:76-82

64. Cekici L, Valipour A, Kohansal R, Burghuber OC (2009) Short-term effects of inhaled salbutamol on autonomic cardiovascular control in healthy subjects: a placebo-controlled study. Br J Clin Pharmacol 67:394-402

65. Vrtovec B, Okrajsek R, Golicnik A, Ferjan M, Starc V, Radovancevic B (2005) Atorvastatin therapy increases heart rate variability, decreases QT variability, and shortens QTc interval duration in patients with advanced chronic heart failure. J Card Fail 11:684-690

66. Manzella D, Grella R, Esposito K, Giugliano D, Barbagallo M, Paolisso G (2004) Blood pressure and cardiac autonomic nervous system in obese type 2 diabetic patients: effect of metformin administration. Am J Hypertens 17:223-227

67. Gale SC, Shanker BA, Coyle SM, Macor MA, Choi CW, Calvano SE, Corbett SA, Lowry SF (2012) Continuous enteral and parenteral feeding each reduces heart rate variability but differentially influences monocyte gene expression in humans. Shock 38:255-261

68. Roque AL, Valenti VE, Massetti T, da Silva TD, Monteiro CB, Oliveira FR, de Almeida JÁ, Lacerda SN, Pinasco GC, Nascimento VG, Granja Filho LG, de Abreu LC, Garner DM, Ferreira C (2014) Chronic obstructive pulmonary disease and heart rate variability: a literature update. Int Arch Med 7:43

69. Pinna GD, Maestri R, Torunski A, Danilowicz-Szymanowicz L, Szwoch M, La Rovere MT, Raczak G (2007) Heart rate variability measures: a fresh look at reliability. Clin Sci (Lond) 113:131-140

70. Sandercock GR, Bromley PD, Brodie DA (2005) The reliability of short-term measurements of heart rate variability. Int J Cardiol 103:238-247

71. Eick C, Rizas KD, Meyer-Zurn CS, Groga-Bada P, Hamm W, Kreth F, Overkamp D, Weyrich P, Gawaz M, Bauer A (2015) Autonomic nervous system activity as risk predictor in the medical emergency department: a prospective cohort study. Crit Care Med 43:1079-1086

72. Sykora M, Czosnyka M, Liu X, Donnelly J, Nasr N, Diedler J, Okoroafor F, Hutchinson P, Menon D, Smielewski P (2016) Autonomic impairment in severe traumatic brain injury: a multimodal neuromonitoring study. Crit Care Med 44:1173-1181

73. Ackland GL, labal S, Paredes LG, Toner A, Lyness C, Jenkins N, Bodger P, Karmali S, Whittle J, Reyes A, Singer M, Hamilton M, Cecconi M, Pearse RM, Mallett SV, Omar RZ (2015) Individualised oxygen delivery targeted haemodynamic therapy in high-risk surgical patients: a multicentre, randomised, double-blind, controlled, mechanistic trial. Lancet Respir Med 3:33-41

74. Ackland GL, Whittle J, Toner A, Machhada A, Del Arroyo AG, Sciuso A, Jenkins N, Dyson A, Struthers R, Sneyd JR, Minto G, Singer M, Shah AM, Gourine AV (2016) Molecular mechanisms linking autonomic dysfunction and impaired cardiac contractility in critical illness. Crit Care Med 44:e614-624

75. Stein PK, Schmieg RE Jr, El-Fouly A, Domitrovich PP, Buchman TG (2001) Association between heart rate variability recorded on postoperative day 1 and length of stay in abdominal aortic surgery patients. Crit Care Med 29:1738-1743

76. Karmali S, Jenkins N, Sciusco A, John J, Haddad F, Ackland GL, Investigators P-XS (2015) Randomized controlled trial of vagal modulation by sham feeding in elective non-gastrointestinal (orthopaedic) surgery. Br J Anaesth 115:727-735

77. Bauer A, Kantelhardt JW, Barthel P, Schneider R, Makikallio T, Ulm K, Hnatkova K, Schomig A, Huikuri H, Bunde A, Malik M, Schmidt G (2006) Deceleration capacity of heart rate as a predictor of mortality after myocardial infarction: cohort study. Lancet 367:1674-1681

78. Thuraisingham RA, Gottwald GA (2006) On multiscale entropy analysis for physiological data. Phys A Stat Mech Appl 366:323-332 